\title{
BIBLIOGRAPHY OF BALTIC JOURNAL OF ART HISTORY 2009-2015
}

\section{BALTIC JOURNAL OF ART HISTORY 1, AUTUMN 2009}

Juhan Maiste "Foreword", 3-5

Kaur Altioa "Die Tartuer Marienkirche und die Frage der Bauschule in Tartu im 14. Jahrhundert", 7-30

Kaire Tooming “Late Medieval Decor at St Martin's Church in Martna", 31-47

Andres Tvauri "Late Medieval Hypocausts with Heat Storage in Estonia", 49-78

OjĀRs SPĀRITIS "Some Aspects of Cultural Interaction between Sweden and Latvian part of Livonia in the 17. century", 79-104

Imants LAnCMAnis "Die Arbeiten des Stuckateurs Johann Michael Graff in Põltsamaa - ein Rokoko-Kunstwerk zwischen Berlin und Kurland", 105-131

EPI TOHVRI

"Der Lehr- und Vorlesungsplan des Lehrstuhls für Wirtschaft, Technologie, Forstwirtschaft und bürgerliche Baukunst der Universität zu Tartu 1803-1828", 135-152

EERO Kangor

"Art Historical Photograph Collection of the University of Tartu. From the Past to the Future", 153-178

Juhan Maiste "Phenomenological Alma mater. Borders of the Visible and the Invisible in Heritage Protection", $181-216$ 
BALTIC JOURNAL OF ART HISTORY 2, SPRING 2010 (VILLEM RAAM 100)

Anneli Randla “Villem Raam 100", 5-8

Kaur Alttoa "Die mittelalterliche Architektur Estlands und Villem Raam", 11-32

Tilna Kala

“Ergänzungen zu den an der Nikolaikirche in Reval/Tallinn in der zweiten Hälfte des 15. und dem ersten Viertel des 16. Jahrhunderts arbeitenden Meistern und Arbeitern", 33-62

JAAN TAMM

Villu KadAKas

"New Data on the First Stone Church of Jõelähtme", 97-115

ANU MäND

"On Two Medieval Seal Matrices and the Guild Seals from Tallinn", 117-138

Krista Andreson "Das Kruzifix in der Kirche von Klein St. Johannis / Kolga-Jaani. Über Kontakte Livlands mit dem Rheinland in der ersten Hälfte des 14. Jahrhunderts", 139-167

Aivar Kritska, "Mittelalterliche Überreste in der Lutsu-Straße RaIDo Roog, Kaur Alttoa 2, Tartu. Vorläufige Forschungsergebnisse", $171-200$

Ain Mäesalu

“Estlands schönste Streitkeule des 12.-13. Jahrhunderts", 201-220

Lars Olof Larsson “Begegnungen mit Villem Raam”, 223-226

Knut Drake “Mein lieber Freund Villem”, 227-233 
BALTIC JOURNAL OF ART HISTORY 3, AUTUMN 2011/ SPRING 2012 (HELMI ÜPRUS 100)

Anneli Randla “Helmi Üprus 100", 7-14

Juhan Maiste "Helmi Üprus und der Klassizismus", 17-55

Lilian Hansar "Helmi Üprus and the Old Town of Tallinn“, $57-76$

Olev Suuder "Inventory of Manors - Future of the Past" 77-86

Kerttu Palginõmm “Luxusartikel auf dem Revaler Retabel des Meisters der Lucialegende als eine Einladung in die Stadt Brügge", 89-114

OjĀrs Spāritis "Transcription of Renaissance HumanismAffected Iconography in Early Protestant Art in Riga", 115-136

AnNe LiLl

"Myths of Pompeii: Reality and Legacy", 139-180

INGE KUKK

"Vervielwältigtes Pompeji - von Graphikblättern bis zur Wanddekoration", 181-213

Tinna-Mall Kreem “Das Kaali-Echo von Pompeji oder ein Hinweis auf die Quellen der Kunst Otto Friedrich von Moellers", 215-223

Hilk K A Hilop "In the Footsteps of Classical Antiquity. Influences of the Antique in Estonian Manor Murals", 225-252

Vija Strupule "Reflections of Antique Art in the Interior Paintings of Residences and Manor Houses in Latvia. The second half of the $18^{\text {th }}$ century - the first quarter of the $19^{\text {th }}$ century", $253-280$

Serguei Androsov "Collection de la Grande Duchesse Marie Nicolaévna et de Karl Eduard von Liphart", 283-302 
INGRID SAHK "Geteilte Freude und gelehrsame Abende. Über die Graphiksammlung und die künstlerischen Abende im Haus des Kunstkenners Karl Eduard von Liphart", 303-327

JaAnika Anderson "Enchantment of the casts - Karl Morgenstern at the University of Tartu Art Museum (18031837)", 329-348

Gerd-Helge Vogel “Johann Wilhelm Krauses Entwürfe für eine Badeanstalt in "Embach Athen" und das Ideal einer Platonischen Republik", 351-372

Anu Ormisson-LAhE "Farbe im Interieur der ersten Gebäude der Universität Tartu (Dorpat)", 373-386

Georgij Smirnov "Materialien zur Geschichte der Architektur und des Städtebaus Estlands im 18. Jahrhundert in der Sammlung des Russischen Staatlichen Archivs Alter Akten", 389-440

Kaur Alttoa, "Über die Bürgerhäuser des mittelalterlichen Aivar KriIsKA Narwas", 441-463

\section{BALTIC JOURNAL OF ART HISTORY 4, AUTUMN 2012}

Kaur Alttoa

"Die so genannte Zwickelkolonette in den Kirchen auf Saaremaa (Ösel)", 7-41

ANU MÄND, "Sacred Space and Corporate Identity: the Black Anneli Randla Heads' Chapels in the Mendicant Churches of Tallinn and Riga", 43-80

Krista Andreson "Der Schöne Christus aus St. Katharinen (Kadrina). Ergänzungen zu den Kunstkontakten des Gebiets des Deutschen Ordens in der ersten Hälfte des 15. Jahrhunderts", 81-115 
Kerttu Palginõmm “Der dem Meister der Lucialegende zugeschrie bene Revaler (Tallinner) Retabel - kostbare Stoffe und ein unbekannter Meister?", 117-141

Ieva Ose

“Einige Anmerkungen zum Einfluss Niederländischer Gravüren auf die Verzierung der Ofenkeramik im Ostseeraum am Anfang des 17. Jahrhunderts", 143-166

Kaur Alttoa, "Materialien zur Kirche in Sääre (Zerel) auf Merike Kurisoo Saaremaa (Ösel)", 171-192

TÕNIS TATAR "Birth of a City from the Spirit of the Autumn School", 197-205

\section{BALTIC JOURNAL OF ART HISTORY 5, SPRING 2013}

Volli Kalm

Juhan Maiste

Ülo Matjus

Kaisa Broner-Bauer

LiLian Hansar

Anti Randvili

Achim Timmermann

Kaur Alttoa
"Foreword", 5-6

“This City and Another", 9-34

“Die Stadt als Erinnerung: unzeitgemässe Notizen", 35-50

"Quo Vadis Civitas? - Thoughts on the European Conception of the City Today", 51-73

“Die Stadt als Utopie", 75-109

"The Art of Utopia and the Real City: Basic Principles", 111-130

"Good and Bad Prayers, before Albertus Pictor: Prolegomena to the History of a Late Medieval Image", 131-178

"Die St. Michaeliskirche in Wiek - eine Wehrkirche?", 179-200 
JAAK Kangilaski "An Interim Summary of a Vast and On-going Work", 205-210

HiLKKA HiIOP

“The Artist's Fingerprint. The Manufacturing Technique in Johann Köler's fresco Come unto Me, All...", 211-230

BALTIC JOURNAL OF ART HISTORY 6, AUTUMN 2013

Kaur Alttoa

“Die Kirche zu Urbs/Urvaste und die Frage der Rigenser Bauschule im 13. Jahrhundert", 7-46

Ragnar NuRK

“Eine Aussicht auf Reval (Tallinn) samt ihrer Befestigungen", 47-68

Linda Lainvoo

"Sociopolitical Mess ages in Eastern Orthodox Church Buildings of the Era of Alexander II in Pärnu County", 71-95

Andris TeIKMAnis

“Toward Models of Socialist Realism”, 97-121

Kurmo Konsa

"Heritage as a Socio-Cultural Construct: Problems of Definition", 123-149

Juhan Maiste

"Kadriorg: the Spirit of Baroque and the Will of Genius. A Palace on the Edge of the Third Rome", 153-176

Anneli Randla "Medieval Painted Decoration in St Michael's Church in Mihkli, Estonia", 179-183

HiLkKa Hiiop, "A Newly Conserved Plafond Painting En riches Eva TAmMeKivi the Old Town of Tallinn", 185-192

“Art and Religion", 193-203 


\section{BALTIC JOURNAL OF ART HISTORY 7, SPRING 2014}

Krista Andreson

ANU MäND

Reet Pius

Anne Kull

Sirje Helme

ELNARA TAIDRE

Juhan Maiste

HiLKKa HiIOP,

AnNeli Randla
"Foreword", 5-7

"Vicarius, Canonicus Et Episcopus: Three Late Medieval Grave Slabs from Tartu and Tallinn", $11-30$

"The Altar Pulpit in Estonian Church Interiors", $31-58$

"How to Ask Questions About Art and Theology?", $59-80$

"Theosophy and the Impact of Oriental Teaching on the Development of Abstract Art", 81-109

“Kazimir Malevich's Suprematism and Modernist Artistic Mythology as an Alternative to Religion", $111-134$

"Art and Truth", 135-167

"Medieval Painted Saints Meeting Modern Media. Project: “Rode Altarpiece in Close-Up"',', 171-180

\section{BALTIC JOURNAL OF ART HISTORY 8, AUTUMN 2014}

Krista Andreson "The Presence of the Sacred: A $13^{\text {th }}$ century cult image from Saaremaa (Estonia)", 7-43

Juhan Maiste "Salvation Through Religion. The Rebirth Of The Classics In Arent Passer's Oeuvre", 45-118

TIINA-ERIKA "The Use and Abuse of Performa-

FRIEDENTHAL, tive Arts for Religion and Society", 119-156

Meelis Friedenthal 
ANNE KOKKOV "Intentionality of Colours in Konrad Mägi's Paintings", 157-188

Merike Kurisoo, Krista Andreson

Kadi Polli

Sirje Helme
"Images and Objects in Ritual Practices in Medieval and Early Modern Northern and Central Europe. Editors Krista Kodres, Anu Mänd. Cambridge Scholars Publishers, 2013", 191-197

"Autumn School of The University of Tartu's Department of Art History: Art and Beauty", 198-207

“Jaak Kangilaski - Scholar and Teacher”, 208-214

\section{BALTIC JOURNAL OF ART HISTORY 9, SPRING 2015}

OJĀRS SPĀRITIS "Foreword", 5-7

Thomas DaCosta "Baltic Reflections", 11-22

KAUFMANN

Ojārs Spāritis „Evidence of the Reformation and Confessionalization Period in Livonian Art", 23-74

INGA LENA "Swedish Church Art from the Introduction of ÅnGSTRÖM GRANDIEN the Reformation in 1527 until the Synod in Uppsala 1593", 75-113

Simon McKeown "Configuring Virtue: The Emergence of Abstraction, Allegoresis and Emblem in Swedish Figural Sculpture of the Seventeenth Century", 115-148

WERNER VON Sengbusch

“Der Kerckring-Altar von Jacobus van Utrecht. Lübecker Meister von 1520 aus der Brederloschen Gemäldesammlung in Riga, heute im St. AnnenMuseum der Hansestadt Lübeck Als Stiftung der Familie von Sengbusch", 149-174 
Juhan Maiste

Kaur Alttoa

HilkKa HiIOP

Holger Rajavee
"A Genius and His Myth: The Known and Unknown Michel Sittow", 177-221

"Die Gewölbekomposition der Kirche in Luggenhusen/Lüganuse", 225-237

"What is Under the Paint Layer of the Rode Altarpieces?", 239-253

“On Tõnis Tatar's PhD thesis The Third Way in Soviet Estonian Art: Between the Avant-garde and the Power-minded", 255-258

\section{BALTIC JOURNAL OF ART HISTORY 10, AUTUMN 2015}

EnN TARVEL

Gerd-Helge Vogel

Kurmo Konsa

Kristi ViIding, AnNi ARUKask, Kaidi Krissa,

Tuuli Triin Truusalu, Maria-KristiInA LotMAN

Kristinna Tiideberg, "Results of the Reasearch Conducted in 2014 on HilkKa Hilop, TiINA Vint, Kristina Aas, the Interior Finishing of the Rotunda in the University of Tartu's Old Anatomical Theatre", 105-128

Grete Nilp, Kaisa-Pina Pedajas, Helen Volber
“Foreword", 5-8

"August Matthias Hagen (1794-1878) - Deutschbaltische Landschaftsmalerei zwischen roman tischem Aufbruch und provinzieller Selbstgenügsamkeit", 11-52

"Modern Conservation: Connecting Objects, Values and People", 53-84

"Ramus Poeticus. Zur lateinischen Grabinschrift auf dem Sarkophag von Thomas Ramm in der Tallinner Domkirche", 85-102 
Kaur Alttoa

TÕNNO JONuKS, Ragnar SAAGE

Holger Rajavee
"Die St. Katharinen-Kapelle in Fellin (Viljandi)", 131-146

"An Antiquarian Gift - a Collection of Perm Animal-Style Plaquettes in Estonian History Museum", 147-166

"Myth. Genius. Art: The Autumn School of Department of Art History of the University of Tartu", 167-170 